\title{
Kuntoluokan ja elopainon muutoksen sekä maidon rasva-valkuaissuhteen yhteys laskennalliseen energiataseeseen
}

\author{
Mäntysaari Päivi1 ${ }^{1)}$, Huhtanen Pekka ${ }^{2)}$, Nousiainen Juha ${ }^{3)}$ ja Mäntysaari Esa ${ }^{4)}$ \\ ${ }^{1)}$ MTT, Kotieläintuotannon tutkimus, 31600 Jokioinen \\ ${ }^{2)}$ Cornell University, Department of Animal Science, Ithaca, NY 14853-4801, USA \\ ${ }^{3)}$ Valio Oy, PL10, 00039 Valio \\ ${ }^{4)}$ MTT, Biotekniikka-ja elintarviketutkimus, 31600 Jokioinen
}

\section{Tiivistelmä}

Lehmien tuotantokyvyn jalostus on johtanut paitsi tuotosten niin myös lehmien elopainon ja syöntikyvyn lisääntymiseen. Syöntikyvyn lisääntyminen ei kuitenkaan ole riittävä kattamaan suurempien tuotosten ja kookkaampien eläinten ylläpidon vaatimaa energiatarvetta, joten lehmät joutuvat lypsykauden alkussa mobilisoimaan puuttuvan energian kudosvarastoistaan. Tästä johtuen lehmien energiatase (EB) on lypsykauden alussa lähes poikkeuksetta negatiivinen. Runsas kudosvarastojen mobilisointi ei ole suotavaa, sillä se johtaa usein heikentyneeseen hedelmällisyyteen ja lisääntyneeseen sairastavuuteen. Energiataseen laskemista varten tarvitaan paitsi tuotos- ja elopainotiedot niin myös tiedot rehunsyönnistä ja rehujen koostumuksesta $(E B=$ syöty energia maidon energia - ylläpitoenergia). Rehun syöntikyvyn tai syöntitietojen perusteella lasketun EB huomioiminen jalostusvalinnassa on ongelmallista, koska syödyn rehun määrän luotettava mittaaminen tilatasolla on nykyisin menetelmin hankalaa. Energiataseen huomioiminen jalostusvalinnassa edellyttääkin helpompaa menetelmää taseen arvioimiseen. Tämän tutkimuksen tavoitteena oli selvittää kuntoluokan ja elopainon muutoksen sekä maidon rasva-valkuaisuhteen ( $\mathrm{R}-\mathrm{V}$ suhde) käyttökelpoisuutta EB indikaattorina.

Tutkimuksen aineisto koostuu MTTn Rehtijärven ASMO-karjassa vuosina 1998-2001 tehdyissä ruokintakokeisssa kerätystä datasta. Kokeissa oli kaikkiaan 146 ensikkoa. Kokeissa lehmiä ruokittiin seosrehulla, joka sisälsi säilörehua ja väkirehua sekä kahdessa kokeessa myös tuoreleikettä $100 \mathrm{~g} / \mathrm{kg}$ ka. Koeruokinnat poikkesivat toisistaan dieetin väkirehu- ja valkuaispitoisuuden suhteen. Keskimäärin väkirehua oli koedieeteissä $470 \mathrm{~g} / \mathrm{kg} \mathrm{ka}$ ja se vaihteli koeasetelman mukaan $450-570 \mathrm{~g} / \mathrm{kg} \mathrm{ka}$. Seosten väkirehun valkuaispitoisuus puolestaan vaihteli $170-210 \mathrm{~g} / \mathrm{kg}$ ka. Koeaineisto sisälsi ensikoiden viikoittaiset keskimääräiset rehunsyönti- ja tuotostiedot. Maidon pitoisuudet oli määritetty neljän viikon välein. Elopaino perustui rinnanympärysmittauksiin, rinnanympärys mitattiin koekaudella 5-7 kertaa kokeesta riippuen. Kuntoluokka arvioitiin neljän viikon välein. Havaintojen perusteella eläimille laskettiin viikoittaiset EB. EB-laskuissa energiantarve ylläpitoon ja maidontuotantoon laskettiin MTT 2006 Rehutaulukot ja Ruokintasuositukset- julkaisussa annettujen ylläpito ja maidontuotanto energiantarvekaavojen mukaan. Laskettu keskimääräinen $\mathrm{EB}$ oli ensimmäisinä laktaatioviikkoina selvästi negatiivinen ollen alhaisimmillaan $-31 \mathrm{MJ} \mathrm{ME} / \mathrm{pv}$. Positiiviseksi energiatase muuttui keskimäärin viikolla 11. Keskimääräiset elopainon ja kuntoluokan muutokset tukivat hyvin laskettua EB:tta. Elopaino laski aina viikolle 9 ja kääntyi nousuun viikolla 12. Kuntoluokka oli alhaisimmillaan viikolla 10, jonka jälkeen lähti hitaaseen nousuun. Elopainon muutoksen, kuntoluokan muutoksen sekä maidon R-Vsuhteen korrelaatio laskettuun EB oli kohtalainen. Rasva-valkuaissuhteella korrelaatio oli vierova ja kuntoluokka ja elopainon muutos olivat positiivisessa yhteydessä EB. Elopainon muutoksen ja EB:n välinen korrelaatio oli hieman alhaisempi kuin R-Vsuhteen ja kuntoluokan muutoksen korrelaatio EB:een. Regressio-analyyseissä testattiin eläimen elopainon, kuntoluokan, R-V suhteen, näissä tapahtuneen muutoksen sekä em. tekijöiden yhdysvaikutusten kykyä ennustaa ensimmäisen poikimisen jälkeisen koelypsyviikon energiatasetta. Parhain energiatasetta kuvaava regressio-yhtälö pystyi kuvaamaan vain $32.6 \%$ EBn vaihtelusta. Tärkeimmät selittävät tekijät olivat R-V suhde ja kuntoluokan muutos.

Asiasanat: Lypsylehmä, energiatase 


\section{Johdanto}

Lehmien tuotantokyvyn jalostus on johtanut paitsi tuotosten niin myös lehmien elopainon ja syöntikyvyn lisääntymiseen (Coffey, et al. 2004). Syöntikyvyn lisääntyminen ei kuitenkaan ole riittävä kattamaan suurempien tuotosten ja kookkaampien eläinten ylläpidon vaatimaa energiatarvetta (Van Arendonk ym., 1991). Koska lehmien rehunhyväksikäyttökyky ei jalostusvalinnan seurauksena ole oleellisesti parantunut, joutuvat lehmät lypsykauden alkupuoliskolla mobilisoimaan puuttuvan energian kudosvarastoistaan. Tästä johtuen ovat lehmät lypsykauden alussa lähes poikkeuksetta negatiivisessa enegiataseessa (Coppock 1985, Coffey ym. 2002). Runsas kudosvarastojen mobilisointi lypsykaudenalussa ei ole suotavaa, sillä se johtaa usein heikentyneeseen hedelmällisyyteen (Butler \& Smith 1989, Senatore ym. 1996) ja lisääntyneeseen sairastavuuteen (Collard ym. 2000).

Energiataseen (EB) laskemista varten tarvitaan paitsi tuotos- ja elopainotiedot niin myös tiedot rehunsyönnistä ja rehujen koostumuksesta $(\mathrm{EB}=$ syöty energia - maidon energia - ylläpitoenergia). Rehun syöntikyvyn tai syöntitietojen perusteella lasketun energiataseen huomioiminen jalostusvalinnassa on ongelmallista, koska syödyn rehun määrän luotettava mittaaminen tilatasolla on nykyisin menetelmin hankalaa. Energiataseen huomioiminen jalostusvalinnassa edellyttääkin helpompaa menetelmää taseen arvioimiseen. Negatiivisessa EB:ssa olevat lehmät pudottavat painoaan ja myös niiden kuntoluokka laskee, joten elopainon ja kuntoluokan muutokset kuvastavat eläimen EB:tta (Heuer ym. 2000). Myös maidon pitoisuudet ja niiden väliset suhteet heijastavat lehmän EB:tta (Heuer ym. 2000, Reist ym. 2002). Maidon R-V suhteen käyttö energiataseen indikaattorina perustuu siihen, että lypsykauden alussa kudoksista mobilisoidaan runsaasti rasvahappoja maitorasvan synteesiin, mutta vain rajoitetusti aminohappoja maitovalkuaisen synteesiin, joten rasvapitoisuus suhteessa valkuaispitoisuuteen nousee. Lypsykauden edetessä R-V suhde laskee, kun syönnin lisääntyessä dieetistä peräisin olevien aminohappojen saanti lisääntyy ja kudosvarastojen mobilisointi vastaavasti vähenee ja muuttuu lopulta varastojen täydentämiseksi. Tämän tutkimuksen tavoitteena oli selvittää kuntoluokan ja elopainon muutoksen sekä maidon R-V suhteen käyttökelpoisuutta EB:een indikaattorina.

\section{Aineisto ja menetelmät}

Tutkimuksen aineisto koostuu MTTn Rehtijärven ASMO-karjassa vuosina 1998-2001 tehtyissä ruokintakokeisssa kerätystä datasta. Koelehminä oli 146 ensikkoa. Ensikot olivat kokeissa ensimmäisen laktaatiokauden, mutta energiataselaskelmissa käytimme tarkasteluun vain laktaatioviikkojen 1-28 aineistoa (viikkohavaintoja 3942). Koeruokintoja oli kokeissa yhteensä 10. Kaikissa kokeissa lehmiä ruokittiin seosrehulla, joka sisälsi säilörehua ja väkirehua sekä kahdessa kokeessa myös tuoreleikettä $100 \mathrm{~g} / \mathrm{kg}$ ka. Koeruokinnat poikkesivat toisistaan dieetin väkirehu- ja valkuaispitoisuuden suhteen. Keskimäärin väkirehua oli koedieeteissä $470 \mathrm{~g} / \mathrm{kg} \mathrm{ka}$ ja se vaihteli koeasetelman mukaan 450 - $570 \mathrm{~g} / \mathrm{kg}$ ka. Seosten väkirehun valkuaispitoisuus puolestaan vaihteli 170 $-210 \mathrm{~g} / \mathrm{kg} \mathrm{ka}$.

Kokeissa ensikoille laskettiin viikoittainen keskimääräinen rehunsyönti (päivittäiset mittaukset) ja maitotuotos (mitattiin kolmena päivänä viikosta). Maidon pitoisuudet määritettiin neljän viikon välein. Elopaino perustui rinnanympärysmittauksiin. Rinnanympärys mitattiin kahdessa kokeessa viisi kertaa lypsykauden aikana ja yhdessä kokeessa mittauskertoja oli seitsemän. Kuntoluokka arvioitiin asteikolla 1 - 5 (Lowman ym. 1976) kahden arvioijan toimesta neljän viikon välein. Kuntoluokkana käytettiin arvioitsijoiden antamien kuntoluokkien keskiarvoa. Tarkemmat tiedot koeasetelmista ja kokeiden tuloksista löytyy tutkimusten julkaisuista (Mäntysaari ym. 2003, Mäntysaari ym. 2004, Mäntysaari ym. 2005). Poiketen julkaisusta rinnanympärys muunnettiin nyt elopainoksi käyttäen MTT:n karjan mitta-painotietojen pohjalta ensikoille laskettua muuntoyhtälöä (Mäntysaari \& Mäntysaari 2007). Kunkin laktaatioviikon paino ja kuntoluokka määritettiin mitattujen painojen ja arvioitujen kuntoluokkien perusteella lasketulla yksilökohtaisella kolmannen asteen regressiolla.

Havaintojen perusteella eläimille laskettiin viikoittaiset EB:t. Energiataselaskuissa energiantarve ylläpitoon ja maidontuotantoon laskettiin MTT 2006 Rehutaulukot ja Ruokintasuositukset- julkaisussa annettujen ylläpito ja maidontuotanto energiantarvekaavojen mukaan (MTT 2006). Eläinkohtaisia keskiarvoja tarkasteltiin sekä lypsykausikohtaisesti että laktaatioviikoittain. Energiataseen ja tarkasteltavien muuttujien välisiä yhteyksiä tarkasteltiin korrelaation ja regression avulla (SAS GLMproseduuri). Regressioyhtälön tavoitteena oli kuvata lehmäkohtaista EB:tta lypsykauden alussa. Selittävinä muuttujina käytettiin tilaolosuhteissakin mitattavissa olevia kuntoluokkaa, elopainoa, 
maidon R-V suhdetta sekä niiden muutoksia. Koska maidonpitoisuudet oli mitattu vain neljän viikon välein, laskettiin $R-V$ suhteen ja EB:n välinen korrelaatio myös käyttäen vain mittaviikkojen arvoja.

\section{Tulokset ja tulosten tarkastelu}

Koeaineiston keskimääräiset lehmäkeskiarvoista lasketut maitotuotos ja -pitoisuus sekä syöntitiedot on annettu taulukossa 1. Aineiston lehmien keskimääräinen maitotuotos päivässä oli $26,4 \mathrm{~kg}$, minimin ollessa 16,5 kg ja maksimin 36,8 kg. Syönneissä vastaavat luvut olivat 17,4 kg kuiva-ainetta/pv (keskiarvo), 10,6 kg ka/pv (min) ja 25,7 kg ka/pv (max). Lypsykauden keskimääräinen elopaino oli suurimmalla lehmällä $684 \mathrm{~kg}$ ja pienimmällä $455 \mathrm{~kg}$, keskimääräisen ollessa $572 \mathrm{~kg}$.

Taulukko 1. Koeaineiston (N=146) keskiarvot sekä minimi ja maximiarvot laskettuna lehmäkohtaisista keskiarvoista (lypsyviikot 1-28).

\begin{tabular}{|l|c|l|l|l|}
\hline & Keskiarvo & Hajonta & Minimi & Maximi \\
\hline Tuotos, kg/pv & & & & \\
Maito & 26,4 & 3,54 & 16,5 & 36,8 \\
EKM & 27,5 & 3,41 & 17,9 & 35,5 \\
Maidon pitoisuudet, g/kg & & & & \\
$\quad$ Rasva & 41,7 & 3,5 & 32,9 & 52,0 \\
Valkuainen & 34,0 & 1,8 & 29,3 & 38,5 \\
Laktoosi & 50,8 & 1,2 & 46,6 & 53,6 \\
Rasva-valkuaissuhde & 1,23 & 0,09 & 1,06 & 1,45 \\
Syönti, kg ka/pv & 17,4 & 2,94 & 10,6 & 25,7 \\
Säilörehua & 9,1 & 1,59 & 5,7 & 14,0 \\
Väkirehua & 8,3 & 1,56 & 4,9 & 12,5 \\
Energiaa, ME MJ/pv & 203,3 & 35,0 & 123,0 & 298,0 \\
Valkuaista, kg/pv & 2,93 & 0,53 & 1,77 & 4,43 \\
OIV, kg/pv & 1,75 & 0,31 & 1,05 & 2,56 \\
Elopaino, kg & 572 & 41,7 & 455 & 684 \\
Kuntoluokka & 3,05 & 0,27 & 2,42 & 4,14 \\
Energiatase, ME MJ/pv & -1 & 34,6 & -78 & 103 \\
\hline
\end{tabular}

Kuvassa 1 on kuvattu maitotuotoksen, syönnin ja energiataseen keskimääräisiä muutoksia lypsykauden aikana. Lypsykäyrä on suhteellisen tasainen, johtuen ensikkoaineistosta. Ensikot eivät heru yhtä korkealle kuin vanhemmat lehmät ja pitävät maitonsa paremmin laktaatiokauden edetessä (Coffey et al. 2004). Maitotuotos saavutti maksiminsa keskimäärin laktaatioviikolla 9 ja kuivaainesyönti puolestaan viikolla 18. Laskettu EB oli lypsykauden alussa selvästi negatiivinen ollen alhaisimmillaan ensimmäisellä laktaatioviikolla -31 MJ ME/pv. Positiiviseksi EB muuttui viikolla 11. Yhtenevästi meidän tulosten kanssa Coffeyn ym. (2002) ja Berryn ym. (2006) aineistoissa ensikot saavuttivat positiivisen EB:n laktaatiopäivinä 72 ja 71 . Kumulatiivinen EB kääntyi positiiviseksi viikolla 28. Kuvassa 1 on esitetty myös keskimääräinen maidon $\mathrm{R}-\mathrm{V}$ suhteen muutos. Maidon $\mathrm{R}-\mathrm{V}$ suhde laski tasaisesti aina viikolle 29 asti, jonka jälkeen kääntyi hitaaseen nousuun. Korkeimmillaan keskimääräinen R-V suhde oli tässä aineistossa 1,28, mikä jää selvästi alle 1,5, jonka ylittävän suhteen on todettu lisäävän riskiä aineenvaihduntaongelmille (Heuer ym. 1999). Yksittäisellä eläimellä mitattiin tässäkin aineistossa viikkohavainnoissa yli 1,5 arvoja. Korkein arvo oli 1,98.

Keskimääräinen kuntoluokan ja elopainon muutos aineistossa on esitetty kuvassa 2. Elopainon ja kuntoluokan muutokset tukevat hyvin laskettua EB:tta. Elopaino laski aina viikolle 9 ja kääntyi nousuun viikolla 12. Kuntoluokka oli alhaisimmillaan viikolla 10, jonka jälkeen lähti hitaaseen nousuun. Ensikoillla kuntoluokan lasku lypsykauden alussa ja vastaavasti kunnon kohoaminen laktaation loppupuolella oli vähäisempää kuin kaksi tai kolme kertaa poikineilla (Coffey ym. 2002). Hitaampi kuntoluokan nousu laktaation edetessä selittyy ensikoilla energian suuntautumisesta kasvuun eikä kudosvarastoihin. 


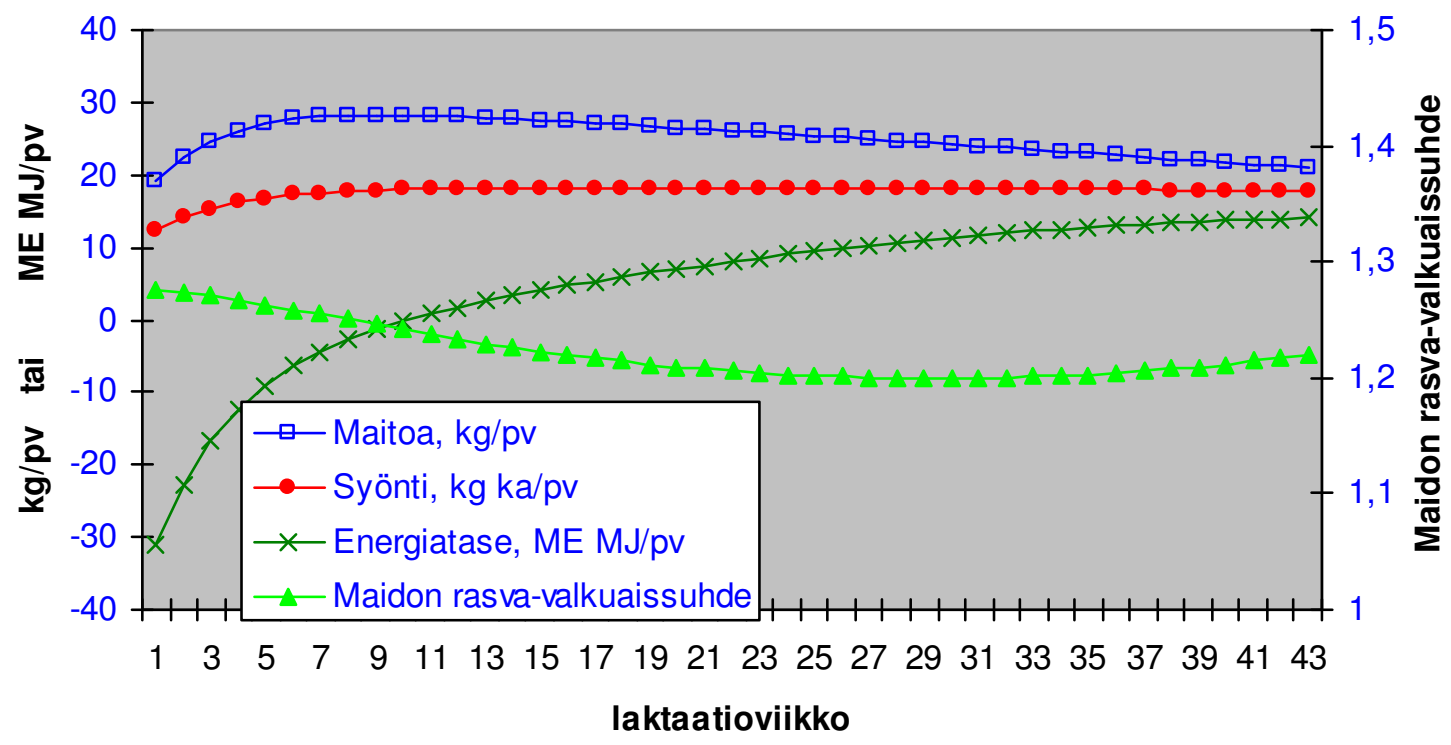

Kuva 1. Maitotuotoksen, syönnin, energiataseen ja maidon rasva-valkuaissuhteen muutokset lypsykauden aikana.

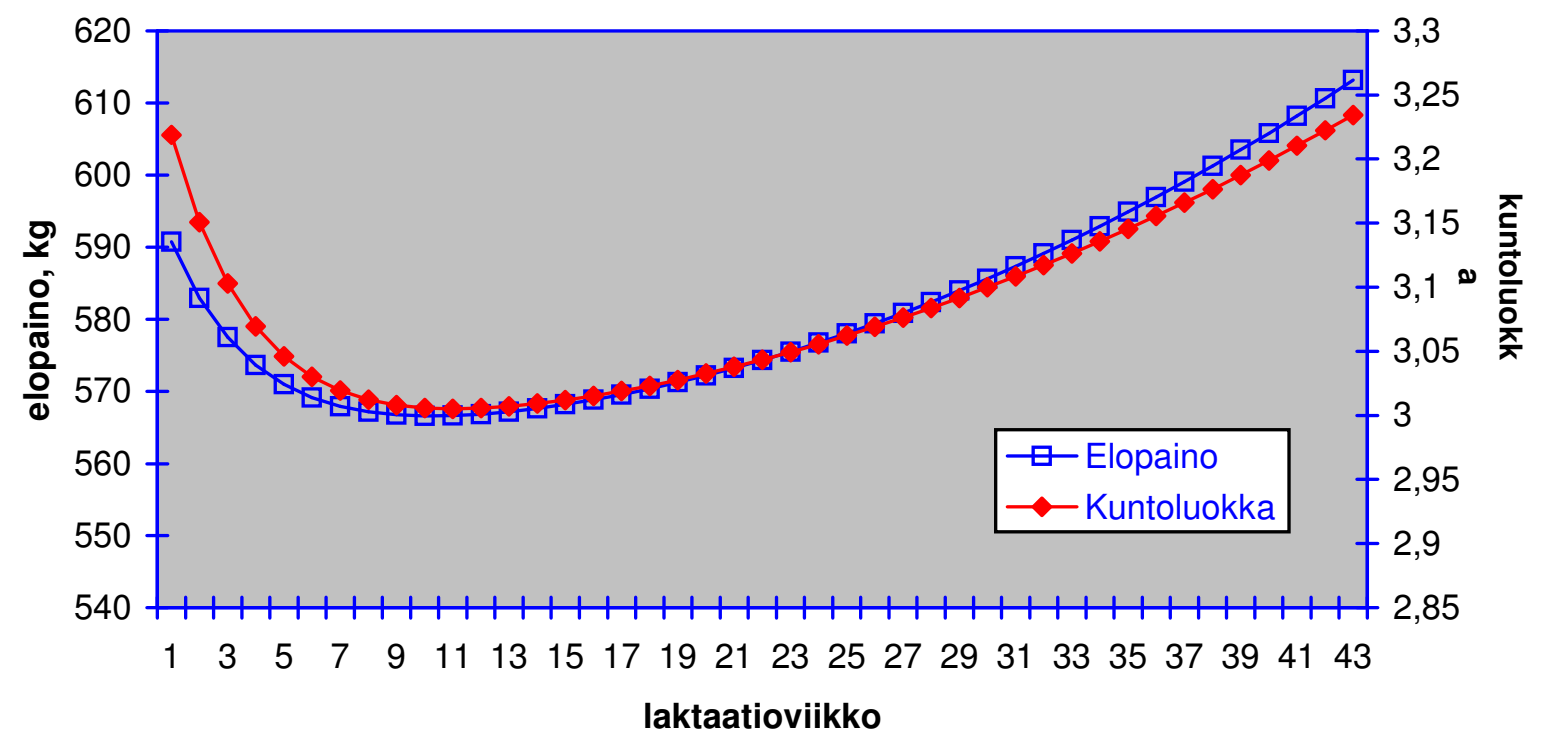

Kuva 2. Koelehmien elopainon ja kuntoluokan muutokset lypsykauden aikana.

Viikoittainen korrelaatio EB:n ja elopainon muutoksen, kuntoluokan muutoksen sekä maidon R-V suhteen välille on esitetty kuvassa 3. Kaikkien kolmen muuttujan korrelaatio laskettuun energiataseeseen oli kohtalainen. Rasva-valkuaissuhteella korrelaatio oli vierova ja vaihteli viikoittain $-0,37$ ja $-0,07$ välillä. Kuntoluokan ja elopainon muutos oli positiivisessa yhteydessä EB:een. Kuntoluokan muutoksen kohdalla viikoittainen korrelaatio vaihteli 0,09 ja 0,39 välillä ja elopainon kohdalla 0,04 ja 0,28 välillä. Suuria muutoksia ei tarkastelujaksolla muuttujien välisissä korrelaatioissa havaittu. Maidon R-V suhde korreloi parhaiten lypsykauden alussa laktaatioviikoilla 24 ja laski energiavajeen vähetessä. Kuntoluokan muutoksen korrelaatio oli voimakkaampi 
tarkastelujakson loppupuolella, jolloin ensikot olivat positiivisessa EB:ssa. Elopainon muutoksen ja EB:n välinen korrelaatio oli hieman alhaisempi kuin maidon R-V suhteen ja kuntoluokan muutoksen korrelaatio EB:een, mutta suhteellisen korkea ottaen huomioon, että elopaino perustui rinnanympärysmittoihin.

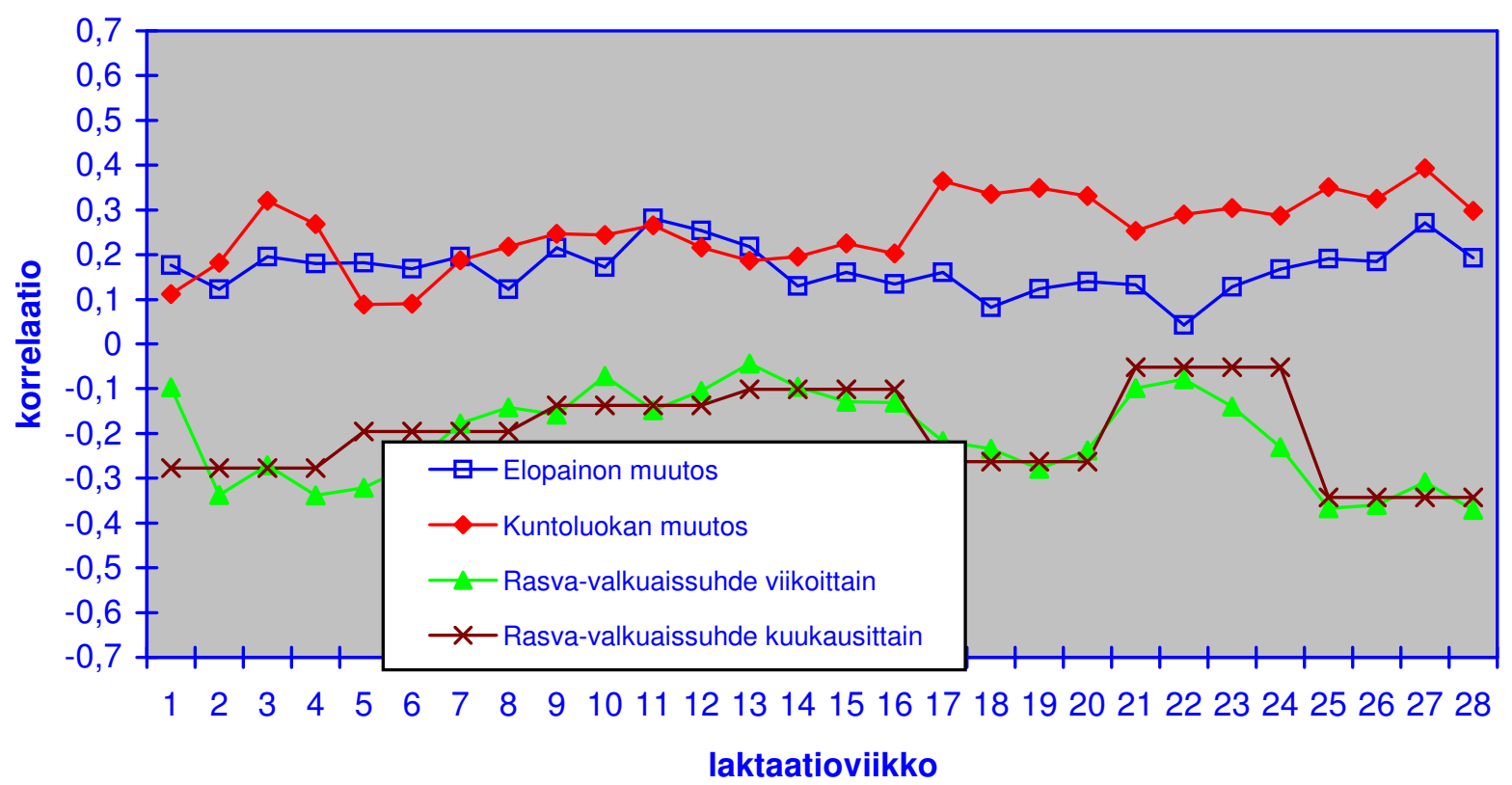

Kuva 3. Elopainon ja kuntoluokan muutoksen sekä maidon rasva-valkuaissuhteen korrelaatio laskettuun energiataseeseen laktaatioviikoittain.

Regressio-analyyseissä testattiin eläimen elopainon, kuntoluokan, R-V suhteen, näissä tapahtuneen muutoksen sekä em. tekijöiden yhdysvaikutusten kykyä ennustaa ensimmäisen poikimisen jälkeisen koelypsyviikon EB:tta. Taulukossa 2 on esitetty parhain EB:tta kuvaava regressio-yhtälö. Se pystyi kuvaamaan vain 32.6 \% EB:n vaihtelusta. Tärkeimmät selittävät tekijät olivat maidon R-V suhde ja kuntoluokan muutos. Kuntoluokan muutoksen vaikutus oli jonkinverran erilainen eri painoisilla lehmillä. Ennusteyhtälön (taulukko 2) mukaan kuntoluokan putoaminen 0,5-yksikköä elopainoltaan $550 \mathrm{~kg}$ ensikolla vaikutti keskimäärin EB:een -60.9 MJ ja elopainoltaan $600 \mathrm{~kg}$ eläimellä -107.1 MJ.

Taulukko 2. Lypsykauden ensimmäisen kuukauden koelypsyviikon energiatasetta kuvaavan regressioyhtälön ratkaisut ja niiden selittämä osuus vaihtelusta.

\begin{tabular}{|l|c|l|}
\hline Regressiotekijä & $\begin{array}{l}\text { Tekijän } \\
\text { regressiokerroin }\end{array}$ & $\begin{array}{l}\text { Kumulatiivinen } \\
\text { selitysaste -\% }\left(\mathrm{R}^{2}\right)\end{array}$ \\
\hline Ruokintakoe LS-keskiarvo & 96,254 & 5,5 \\
\hline Koelypsyn rasva-valkuaissuhde & $-62,722$ & 13,6 \\
\hline Kuntoluokka & $-16,384$ & 14,3 \\
\hline Elopaino & 0,045 & 17,2 \\
\hline Kuntoluokan muutos & $-893,453$ & 30,0 \\
\hline Elopaino*kuntoluokan muutos & 1,846 & 32,6 \\
\hline
\end{tabular}

\section{Johtopäätökset}

Tulokset vahvistivat selvästi poikimisen jälkeisen energiavajeen, joka syntyy kun korkeatuottoisilla ensikoilla maitotuotos nousee nopeammin kuin syöntikyky. Ensimmäisen kuukauden aikana EB oli keskimäärin -21 ME MJ/pv. Vajeen kattamiseksi keskiarvoeläimen olisi syötävä noin $2 \mathrm{~kg}$ kuiva- 
ainetta enemmän. Eläimet korvasivat puuttuvan energian kudosvarastoistaan. Ensimmäisen kuukauden aikana ensikot pudottivat painoaan keskimäärin $17 \mathrm{~kg}$ ja niiden kuntoluokka laski 0,15yksikköä.

Energiataseen ja maidon R-V suhteen välinen korrelaatio vahvisti maidon koostumuksen muuttuvan, kun eläimet käyttävät kudosvarastojaan energialähteenä. Vaikka keskiarvojen perusteella elopainon ja kuntoluokan muutos sekä RV-suhde kuvasivat kohtuullisesti energiatasetta, niin yksittäisillä eläimillä ko. tekijöiden vaikutus EB:een vaihteli. Kokonaisuudessaan yksilöllisen EB:een ennustaminen elopainomuutosten, kuntoluokitusten ja maidon R-V suhteen avulla osoittautui ongelmalliseksi. Energiataseen tarkka mittaus edellyttäisi sekä päivittäistä rehunsyönnin mittausta että myös päivittäisiä tuotoksia ja maidon pitoisuuksia. Toisaalta eläinyksilöillä voi samassa elopainossa ja tuotantotasolla olla eroja tarpeissa, jolloin laskennallinen EB ei kerrokkaan yksilöiden todellista energiavajetta.

\section{Kiitokset}

Tutkimus on osa Maa- ja Metsätalousministeriön, Faba Jalostuksen, Kotieläinjalostuskeskus-FABAn ja Suomen Meijeriyhdistyksen rahoittamaa lehmien rehunkäyttökyky -hanketta

\section{Kirjallisuus}

Berry, D.P., Veerkamp,R.F. \& Dillon, P. 2006. Penotypic profiles for body weight, body condition score, energy intake and energy balance across different parities and concentrate feeding levels. Livest. Sci. 104: 1 12.

Butler, W.R. \& Smith, R.D. 1989. Interrelationships between energy balance and postpartum reproductive function in dairy cattle. J. Dairy Sci. 72:767 - 783.

Coffey, M.P., Simm, G. \& Brotherstone, S. 2002. Energy balance profiles for the first three lactations of dairy cows estimated using random regression. J. Dairy Sci. 85: $2669-2678$.

M. P. Coffey, G. Simm, J. D. Oldham, W. G. Hill, and S. Brotherstone. 2004. Genotype and Diet Effects on Energy Balance in the First Three Lactations of Dairy Cows. J Dairy Sci, 87(12): 4318 - 4326.

Collard, B.L., Boettcher, P.J., Dekkers, J.C.M., Petitclerc, D. \& Schaeffer, L.R. 2000. Relationship between energy balance anf health traits of dairy cattle in early lactation. J. Dairy Sci. 83: 2683 - 2690.

Coppock, C.E. 1985. Energy nutrition and metabolism of the lactating dairy cows. J. Dairy Sci. 68: 3403 3410 .

Heuer, C., Van Straalen, W.M., Schukken, Y.H., Dirkzwager, A. \& Noordhuizen, J.P.T.M. 2000. Prediction of energy balance in a high yielding dairy heard in early lactation: model development and precision. Livest. Prod. Sci. 65: $91-105$.

Lowman, B.G., Scott, N.a. \& Somerville, S.H. 1976. Condition scoring of cattle. The East of Scotland Coll. Agric. Bull. No. 6.

MTT 2006. Rehutaulukot ja ruokintasuositukset [verkkojulkaisu]. Jokioinen: Maa- ja elintarviketalouden tutkimuskeskus. Julkaistu 14.2.2006, [viitattu 10.11.2007]. Saatavissa: http://www.agronet.fi/rehutaulukot/. URN:NBN:fi-fe20041449.

Mäntysaari, P. \& Mäntysaari E. 2007. An evaluation of two indirect methods of estimating body weight in Finnish Ayrshire cows. Käsikirjoitus valmisteilla, julkaisematon.

Mäntysaari, P., Huhtanen, P., Nousiainen, J. \& Virkki, M. 2005. The effect of protein-feeding strategy during lactation on performance of primiparous dairy cows fed total mixed ration. Livest. Prod. Sci. 94: 189-198. Mäntysaari, P., Huhtanen, P., Nousiainen, J. \& Virkki, M. 2004. The effect of concentrate crude protein content and feeding strategy of total mixed ration on performance of primiparous dairy cows. Livest. Prod. Sci. 85, 2-3: 223-233.

Mäntysaari, P., Nousiainen, J. \& Huhtanen, P. 2003. The effect of constant or variable forage to concentrate ratio in total mixed ration on performance of primiparous dairy cows. Livest. Prod. Sci. 82, 1: 27-37.

Reist, M., Erdin, D., von Euw, D., Tschuemperlin, K. Leuenberger, H., Hammon, H.M., Morel; C., Philipona, C., Zbinden, Y., Kuenzi, N. \& Blum, J.W. 2002. Estimation of energy balnce at the individual and herd level using blood and milk traits in high-yielding dairy cows. J. Dairy Sci- 85: 3314 - 3327

Van Arendonk, J.A.M., Nieuwhof, G.J., Vos, H. \& Korver, S. 1991. Genetic aspects of feed intake and efficiency in lactating dairy heifers. Livest. Prod. Sci. 29: 263 - 275. 